\section{A Taql RFLP in the region of the HPRT locus}

P.Renwick, M.Raybould, A.Birley ${ }^{1}$ and M.Hultén

DNA Laboratory, Regional Cytogenetics, East Birmingham

Hospital, Birmingham B9 5PX and 1Population and

Environmental Research Group, School of Biological

Sciences, The University of Birmingham, B15 2TT, UK

Source/Description: EcoRI restriction fragments (total length 18.5 $\mathrm{kb})$ were isolated from the bacteriophage $\mathrm{Hu} \lambda 2$ to provide material for a human genomic DNA probe, MAJ1001. Hu $\lambda 2$ contains genomic DNA sequences derived from the $h p r t$ region (X-chromosome) that are cloned into the EcoRI target sites of the bacteriophage Charon 4A (1). The probe sequence originates from exon 7 and extends $14.4 \mathrm{~kb}$ into the hprt $3^{\prime}$ flanking region.

Polymorphism: This probe revealed a two allele restriction fragment length polymorphism with bands at $1.8 \mathrm{~kb}$ and $2.2 \mathrm{~kb}$ (A1) or $4.0 \mathrm{~kb}$ (A2) after Southern blot analysis of human genomic DNA digested with TaqI.

Frequency: Estimated from 30 unrelated British individuals (44 $\mathrm{X}$-chromosome total). A1 $(1.8+2.2 \mathrm{~kb})=0.89 ; \mathrm{A} 2(4.0 \mathrm{~kb})$ $=0.11$. Of 14 females tested, 4 were heterozygous. No homozygous females were observed for allele A2. Constant bands of $0.4,0.5,0.8,1.0,1.6$ and $3.4 \mathrm{~kb}$.

Chromosomal Location: The hprt gene has been localised to Xq26-27 (2).

Mendelian Inheritance: Codominant inheritance demonstrated in one family EBH1.

Other Comments: (a) The father of family EBH1 also has the $22-\mathrm{kb} / 18-\mathrm{kb}$ allele for the previously described BamHI restriction fragment length polymorphism (3). (b) The presence of repetitive sequences in the probe was overcome by using 'Hybridime' genomic DNA blocking agent in the hybridisations (supplied by Stratech Scientific Limited). (c) Computer studies (4) of the hprt sequence (5) show that the TaqI RFLP is most likely caused by a single nucleotide change in the restriction site beginning at position 50988 which occurs within ALU number 44.

Acknowledgements: Hu 22 was a gift from P.I.Patel, Howard Hughes Medical Institute Laboratory, Baylor College of Medicine, Houston, TX 77030. The work is supported by the Letten F.Saugstads fund.

References: 1) Patel et al. (1986) Mol. Cell. Biol. 6, 393-403. 2) Pai et al. (1980) Proc. Natl. Acad. Sci. USA 77, 2810-2813. 3) Nussbaum et al. (1983) Proc. Natl. Acad. Sci. USA 80, 4035-4039. 4) Devereux et al. (1984) Nucl. Acids Res. 12, 387-395. 5) Edwards et al. (1990) Genomics 6, 593-608.

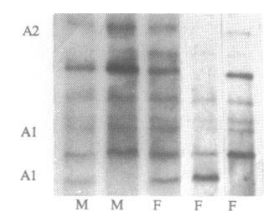

Autoradiographs from the left: male hemizygous for allele Al, male hemizygous for allele $A 2$, female heterozygous for alleles $A 1$ and $A 2$, female homozygous for allele $\mathrm{A} 1$, heterozygous female for alleles $\mathrm{A} 1$ and $\mathrm{A} 2$.

\section{Pstl polymorphism within the $3^{\prime}$ untranslated region of the insulin gene detectable by the polymerase chain reaction (INS)}

Paul R.Hoban and Anna M.Kelsey

Department of Pathology, Royal Manchester Childrens

Hospital (RMCH), Pendlebury, Manchester M27 1HA, UK

Source/Description: Oligonucleotide primers to the $3^{\prime}$ untranslated region of the insulin gene were used to amplify a $221 \mathrm{bp}$ fragment. A sequence variant from within this region has previously been described (1).

\section{PCR primers: 5' AAGCGTGGCATTGTGGAACAAT 3' 5' CTGGGAGGGGCTCACAACAGT 3'}

Method: $1 \mu \mathrm{g}$ of genomic DNA was amplified using $0.5 \mu \mathrm{g}$ of each primer in total volume of $100 \mu \mathrm{g}$ containing $1 \times \mathrm{Taq}$ polymerase buffer (BCL) and $200 \mu \mathrm{M}$ dNTPs. Samples were heated to $97^{\circ} \mathrm{C}$ for $5 \mathrm{~min}$, after which 2 units of Taq polymerase (BCL) were added. Reactions were cycled 30 times at $94^{\circ} \mathrm{C}$ for $1 \mathrm{~min}, 60^{\circ} \mathrm{C}$ for $1 \mathrm{~min}$ and $73^{\circ} \mathrm{C}$ for 2 mins. Restricted PCR products $(10 \mu \mathrm{l}$ aliquots digested in a total volume of $50 \mu \mathrm{l})$ were analyzed by electrophoresis through $3 \%$ agarose gels.

Polymorphism: PstI restriction reveals a two allele system, allele 1 is $221 \mathrm{bp}$ and allele 2 is $137 \mathrm{bp}$ and $84 \mathrm{bp}$.

Frequency: Determined from 70 unrelated individuals.

Allele 1 (A1): 0.71

Allele 2 (A2): 0.29

Heterozygosity is 0.30 (21/70 individuals studied).

Mendelian Inheritance: Codominant segregation was observed in three families (14 individuals).

Comment: As this polymorphism is located within a transcribed region of the insulin gene it should allow the PCR based determination of allele specific expression within RNA samples, in addition to the detection of allele imbalance within DNA samples.

Chromosomal Localisation: The insulin gene has been localised to $11 \mathrm{p} 15.5$ (2).

Acknowledgement: This work was supported by $\mathrm{RMCH}$ from the Pendlebury Leukaemia Research Fund.

References: 1) Ulrich,A. et al. (1980) Science 209, 612-615. 2) Bell,G.I. (1982) Nature 295, 31-35. 